УДК 37:316.324.7]:316.276

DOI https://doi.org/10.26661/hst-2020-7-84-02

\title{
LIFE ACTIVITY ANALYSIS OF EDUCATIONAL SYSTEMS IN THE CONTEXT OF CIVILIZATIONAL DEVELOPMENT OF THE PLANETARY WORLD
}

\author{
(c) ZINKEVYCH, VASYL \\ Drogobych Ivan Franko State Pedagogical University (Drogobych, Ukraine) \\ E-mail: Zinkevych1971@gmail.com \\ ORCID iD: https://orcid.org/0000-0003-1004-1685 \\ Дрогобииький державний педагогічний університет імені Івана Франка, вул. Івана Франка, 24, \\ 82100 Дрогобич, Україна, Львівська область \\ Drogobych Ivan Franko State Pedagogical University str. I. Franko, 24, 82100 Drogobych, Ukraine, Lviv region
}

\begin{abstract}
The article analyzes the dependence of the phenomenon of education on the type of civilization in space of which the life of the world community takes place and is based on the interaction of social institutions of the market, science and education, on the surface which "proceeds" by the division of social labor, which generates a specific form of social system of education already in dependence on the social division of labor in specific socio-economic conditions. To effectively reproduce its structural and functional parameters, the author suggests resorting to the paradigm of the «life cycle of educational systems in the context of a civilizational approach» based on the use of cognitive analysis. Its advantage is only that the concept «grasps» the phenomenon of education as a whole. This means that the phenomenon of civilization education is studied as a social institution and social system of the industrial society.

To analyze the dynamics of knowledge change, two methodological conditions must be used:to apply the civilizational approach and the paradigm of the life cycle of social systems, since this phenomenon has a long-lasting dimension in space and time; it is emphasized that knowledge is the basic and system-forming element of self-deployment of civilization and therefore it can be used (according to Foucault) as a methodological criterion for assessing the quality of life of civilization; the meaning of educational content at each stage of industrial civilization life is distinguished: natural knowledge prevailed at the stage of its origin; at the stage of growth - technical knowledge that corresponded to the essence of civilization itself; at the stage of maturity - scientific knowledge turned into ideologues of social development, which led to the emergence of technocratism and "drove" the planetary community into a dead end; at the stage of decline technological knowledge led to the loss of mainstream guide of social development and began the catastrophic destruction of the social organism of the planet, which entails a change in the type of civilizational development; the solution is seen in the rise of the planetary community into the space of informational civilization, the transition of education to mastering methodological knowledge corresponds to it.
\end{abstract}

Key words: education, industrial civilization, social institute, social system, social division of labor, life cycle, origin, formation, maturity, decline.

Problem statement in general and its connection with important scientific or practical tasks. The current stage development of the world community, being in a prolonged social crisis from the end of the twentieth century, is characterized by a persistent search for an effective variant of the educational system, since it depends on the planetary formation of personal and collective intelligence, capable of capturing its mechanisms and climbing the level of informational civilization. The problem arose due to a number of objective and subjective causes. The problem of retarding the development of fundamental science about the informational day in the context of each individual element of planetary integrity is among them in the first place, on the one hand, it means a complete absence or lack of fundamental knowledge about the mechanisms of its creation (selforganization) and reproduction, both in the horizon of knowledge on personality and society,and certain areas of their interaction - ideology, economics,civil society building, culture, politics, management, ethics and aesthetics, and, on the other hand, strengthening theopposition to traditionalism in the field of national politics, afraid to leave the acquired shell, sometimes by the age of struggle, national independence and statehood, as well as a surge of inertia in the life of scientific, humanitarian, technical and especially military elites, which leads to an increase in the time of cultural lag and a temporary increase in resistance to innovative proposals of the future days.

Analysis of recent researches and publications, which initiated the solution of the given problem, on which the author relies. This problem is constantly in the field of view of foreign and domestic scientists, sociologists, managers, philosophers of education and teachers. Especially the rich material 
for understanding the life cycle of educational systems has been accumulated by modern economics and management. The problem of the life cycle of the enterprise is given considerable attention by domestic and foreign scientists and practitioners, namely: I. Adizes, O. Arefyeva, I. Blank, T.Volkova, N. Rodionova, T. Malaieva, D. Miller, S. Klymchuk. It is for this area that scientists have developed and presented a fairly large number of life cycle models of organizations. Each researcher used various organizational characteristics based on life cycle model and considered a various number of development stages.

Highlighting previously unsolved parts of the general problem to which this article is devoted. Our working hypothesis is that in order to clarify the direction, content and form of selfdevelopment of informational age education, it is necessary to study the life cycle regularity of the social system in industrial education and predict future events in education on their basis.

The aim of the article is to set the content and types of educational systems on the basis of a civilizational approach. We can determine the life cycle in order to predict the algorithm of formation the educational system of the informational agein their functioning.

Main material presentation. Civilizations, as a relatively independent social integrity "are dynamic phenomena that move through various cycles, phases of genesis, growth, maturation, decline and decay" [4, p. 84]. There is no doubt that the educational system lives the same life together with the megastructure in the structure of civilization. It "comes" with this structure and "leaves" with it. Therefore, the cyclical nature of the maternal system affects the rhythm of subsidiary life as its organ in the structure of the whole.

In support of this thesis, we cite the opinion of O. Shpenhler, who proposed, as is well known, the idea of a plurality of equivalent cultures. He determines, based on the factor of culture, the general phases of cyclical development of each of them. The first phase is the phase of the cultureemergence, occurs suddenly, when the transcendental prephenomenon first reveals itself in external manifestations; the second is related to the process of its growth - self-disclosure, self-development of culture, its spiritual content in all spheres of human life activity; the third phase determines the flowering of culture, i.e the state of maximum realization of its internal potentials; the fourth is due to the decline of culture, when the deep possibilities of culture are exhausted and it passes from organic to mechanistic forms. The phase of civilization begins - a period of expansion and militarism, reflection the advantages of the quantitative principle over the qualitative one, which dominates in culture. A sign of the transition to the phase of civilization is "massification", which penetrates into all spheres of human life. Symbols of this process are large cities instead of settlements and small towns. The principle of "massification" finds its addition in the globalization of forms and ways of human existence of the economy, politics, technology, science, and so on. This, in turn, indicates the "civilization" dominance of the principle of space over the principle of time in human life. The fifth phase means physical destruction (antiquity) or ossification (China), when the creative potential of culture has been exhausted [13, p. 592].

The theory of civilization, which is gradually maturing in modern theory of knowledge, also does not provide answers to these questions. Although modern textbooks present the existence of at least three types of theories in this area. H.P. Klimova, for example, in the study "Education as a phenomenon of civilization", notes that civilization is a social organization that has developed historically, and acts as a means and method of society development in the direct production and reproduction of social life andhumanhimself, which has thehereditarytranslation of mankind social experience and the generation of universal material and spiritual values, created during the work of individuals to ensure the selfdevelopment of internal human forces" [5, p. 60]. From what we have just considered, it follows that civilization is a product of human interaction with each other, which meaningfully manifests itself as a type of human connection in the course of both material and spiritual production, and culture is the end product of this productive interaction. Everything seems quite logical: at first new connections are formed between individuals, producers and peoples, and only then the artifacts of the culture of the new era appear. And only then the culture begins to infuse the planetary community of people by means of feedback and stabilizes civilization with its conservative potential, that is, keeps it in a mode of homeostasis.

Confirmation of the above we find in the work of S. Martyniuk "Genesis of informational civilization" [7, p. 192]. But we can not afford a long quotation of other work, although the five approaches to assessing the problem of defining civilization as a specific type of interaction between human 
and society would be of interest to the average reader. Therefore, we refer him to this extraordinary work of the researcher.

Next, it makes sense to emphasize that it is civilization that forms society, not the other way around. Here it is worth paying attention to the definition of this moment in the works of Karl Marks. According to K. Marx, society, "does not consist of individuals, but reflects the amount of those connections and relationships in which these individuals are in relation to each other" [9, p. 222]. In this case, society is a "product of human interaction" [9, p. 402]. This means that the World knowledge society dates back to the future, arises as a result of the formation of qualitatively new connections between people, which they form and maintain in the process of entering the informational age.

In the dictionary "Modern western sociology" (1990) it is proposed to include the whole set of "interaction ways and combination forms of people, which reflects their comprehensive dependence on each another" in the definition of society [12, p. 233]. Therefore, it is quite logical and "more appropriate to determine the amount of connections between people that they form as a society in the process of their life activity and the type of these connections, which is reflected in the way they are implemented - as a civilization" [7, p. 192].

Modern creation and self-reproduction of planetary human is based on qualitatively new types of relations between participants of the world cultural and historical process, in this case there is hegemony of informational interaction in the new society too - World knowledge society, born with the advent of informational civilization. "Interaction between civilizations based on the principle of self-determination can accelerate or slow down, enrich or impoverish development. In the course of interaction, each civilization perceives only those elements that best suit it and do not violate its own individuality" [4, p. 87-88].

Therefore, it is quite natural that culture, as a product of previous stages of the planetary community development, just "determines the humanistic and valuable orientation of civilization" [5, p. 415], regulates interpersonal relations and relations "society-nature", on its basis new relations form a new "historically defined type of personality" [11, p. 4]. We believe that this should be a planetary personality, that is, the world community becomes a Collective personality. In this regard, there are already some theoretical justifications [1, p. 552].
To calculate the stages of the life cycle of educational systems, it is necessary to establish quantitative parameters of existing civilizations, which should reasonably limit the number of objects within which we can reproduce the content and structure of the subject so that it can be used as a methodological tool for predicting self-deployment system of education in the informational age.

At the same time, we must turn to such a classification of civilizations, which is inherent in all planetary humanity, that is, to refuse their territorial and national classifications. Therefore, we dwell on the selection of such stages or types of civilizational system of the planetary social world as: pre-civilization, agrarian, industrial (technocratic), informational, intellectual, cosmic [2, p. 220].

It is time to move on to reproducing the content of educational systems that emerged in the previous stages of civilizational development of the planetary community. We need to do this in order to make sure that: firstly, the educational system is a man-made product, so it has matured over time; secondly, we need to work out tactics to study the problem field it will be a study of the life cycle of the most mature educational system, or we will look for relevant fragments in all kinds of civilizational progress of the world community.

To do this, we turn to the work of K. Korsak, who gave a detailed description of the educational phenomenon in the discourse of pre-agrarian, agrarian, industrial and information societies in the journal "RidnaShlola" ("Native School") in 2002 [6, p. 7]. It has 12 factors that are evaluated by the researcher in each type of society (See: Table 1).

The given comparative table of society and education properties comparison with science can also be found in V. Ohnevyuk's monograph "Education in value system of sustainable human development". Commenting on its factors, he notes: "there are at least eleven important factors that determine the essence of the era in which there is a life activityof the current generation and the value base of which will be determined by Homo educates" [10, p. 380-382]. If we analyze the presented table with the parameters of educational and science system in the relevant time periods of the cultural and historical process, it becomes obvious that the educational system has gradually matured in the space of the respective civilizations.

In the days of industrial society, formed in the space of technogenic civilization, the educational system had finally matured, as evidenced by its 
parametric characteristics, and therefore it had entered a phase of sustainable operation. This means that to reproduce its life cycle we have to consider in detail this period, i.e, from about 1430 to 1955 [3, p. 172-197].

Thus, now we can determine the main boundariesin subject field of the life cycle phenomenon study of the social educational system in the industrial age, as a number of its principles are proved, namely through:

determining the immanent connection of the educational system with civilization, as a form of planetary community life, which passed three stages: agrarian, industrial and entered the information one;

finding a comparative analysis of the twelve parameters formation of the educational system in the space of civilizational self-development of the planetary community in the treasury of domestic scientific thought; establishing the fact that the educational system had reached the greatest degree of maturity during the technocratic era and now it is possible to model the full life cycle of the educational systemon its basis;

identifying a "white spot" in our analysis, since we have not yet established a technological relationship in the ratio of social division of labor and education as a kind of rational human activity, which should be one of its products, because it (the educational system) directly depends on the development of social division principle of labor (production) in which a person participates;

formulatingthe working hypotheses about the education that has two types of existence in the structure of civilization: as a social institution, since it obeys the pulsation of the energyand information field of the maternalstructure and as a social system that depends on human consciousness and gradually matured on the side of transformational society.

Table 1

Defining features of societies and the corresponding characteristics of science and educational systems (according to K. Korsak)

\begin{tabular}{|c|c|c|c|c|}
\hline \multirow{2}{*}{ Characteristics } & \multicolumn{4}{|c|}{ Variants of societies } \\
\hline & Pre-agrarian & Agrarian & Industrial & Informational \\
\hline $\begin{array}{l}\text { 1. "Average" product of the } \\
\text { training system }\end{array}$ & member of the tribe & slave or serf & worker or clerk & $\begin{array}{l}\text { freelance } \\
\text { professional }\end{array}$ \\
\hline $\begin{array}{l}\text { 2. Dominant form of education } \\
\text { (and upbringing) }\end{array}$ & family and flock & family and state & state & $\begin{array}{l}\text { civil, } \\
\text { socialized }\end{array}$ \\
\hline 3. The nature of studying & Natural & direct, individual & mass, standard & $\begin{array}{c}\text { individual, } \\
\text { non-standard }\end{array}$ \\
\hline 4. The basis of studying culture & Example & word and example & printed text and word & $\begin{array}{c}\text { Numerical form of } \\
\text { information }\end{array}$ \\
\hline $\begin{array}{l}\text { 5. General } \\
\text { characteristics of education: } \\
\text { a) compulsory } \\
\text { b) initial * }\end{array}$ & $\begin{array}{l}\text { Education } \\
\text { (as a system) did } \\
\text { not exist }\end{array}$ & $\begin{array}{l}\text { very short } \\
4 \text { years } \\
6 \text { years }\end{array}$ & $\begin{array}{c}\text { lasted } \\
7-9 \text { years } \\
7-13 \text { years }\end{array}$ & $\begin{array}{l}\text { continuous } \\
12-14 \text { years } \\
>20 \text { years }\end{array}$ \\
\hline 6. Educational standards & Absent & local & International & International \\
\hline 7. The value of higher education & did not exist & insignificant & significant & ultimativative \\
\hline $\begin{array}{l}\text { 8. The role of education and sci- } \\
\text { ence in the productive forces of } \\
\text { the country }\end{array}$ & virtually absent & barely noticeable & moderate & Decisive \\
\hline 9. Primary methods & Natural & empiricism & $\begin{array}{l}\text { scientific (division } \\
\text { and analysis) }\end{array}$ & $\begin{array}{l}\text { scientific (division } \\
\text { and analysis) }\end{array}$ \\
\hline 10. Leaders among sciences $* *$ & materials science & $\begin{array}{l}\text { mechanics, } \\
\text { mathematics }\end{array}$ & $\begin{array}{l}\text { physics and } \\
\text { chemistry }\end{array}$ & $\begin{array}{l}\text { biology and } \\
\text { ecology }\end{array}$ \\
\hline 11. The basis of the ideas & Fantasies andmyths & faith and religion & exact sciences & $\begin{array}{l}\text { human and world } \\
\text { sciences }\end{array}$ \\
\hline 12. Object of trust & Myths & belief in God & exact sciences & complex sciences \\
\hline
\end{tabular}

Notes: * Initial Education - all types of training and professional competence from human birth to the moment of entry into the labor market or beginning the duties of a new family member.

** The word "science" is used here in the international sense "Sciences" (non-subject,trustworthy knowledge, obtained as a result of experiments and measurements). 
Conclusions. Thus, the subject of further research is the life cycle of educational systems and presented to us as a dual dynamic process that unfolds in time and space in accordance to the attributive properties of a certain stage evolution of the planetary world: in the structure of the social body of civilization the phenomenon manifests itself as a social institution, which determines the social division of labor and determines its content, and on the side of the social division of labor it manifests itself as a social system that is consciously designed by human for the needs of the day and based on the exchange of educational work with its other varieties. It (the educational system) moves through four stages of life, namely: birth, growth, maturity and decline.

\section{Список використаних джерел}

1. Бех В. П. Фантом планетарного організму: погляд у майбутне : монографія. В. П. Бех, І. А. Грицяк, О. Г. Рябека. Нац. пед. ун-т імені М.П.Драгоманова. Київ : МП «Леся», 2015. 552 с.

2. Бех В. П. На порозі сингулярності: планетарна спільнота у вирі Всесвіту: монографія В.П. Бех, Ю. В. Бех. Нац. пед. ун-т імені М. П. Драгоманова. Київ : МП «Леся», 2014. 220 с.

3. Гринин Л. Е., Гринин А.Л. Кибернетическая революция и шестой технологический уклад. Историческая психология и сочиология истории. № 1. С. 172-197.

4. Ерасов Б. С. Культура, религия и цивилизация на Востоке (Очерки общей теории). Москва : Наука, 1990. C. $87-88$.

5. Климова Г. П. Образование как феномен цивилизации / Дис.на соиск. уч. ст. д. философ. наук. Харьков, 1997. $415 \mathrm{c}$.

6. Корсак К. Освіта і суспільство - дороговкази розвитку. Рідна шикола, 2002. №5. С. 7.

7. Мартинюк С. Є. Генезис інформаційної цивілізації: монографія. Запоріжжя : Просвіта, 2002. 192 с.

8. Маркс К. К Павлу Васильевичу Анненкову, 28 декабря. Маркс К., Энгельс Ф. Сочинения. - 2-е изд. Т. 27. Москва : Изд-во политической литературы, 1975. $402 \mathrm{c}$.

9. Маркс К., Энгельс Ф. Экономические рукописи 1857-1859 гг. Маркс К., Энгельс Ф. Сочинения. - 2-е, Т. 46, ч. 2. Москва : Изд-во политической литературы, 1969. 222 с.

10. Огнев'юк В. Освіта в системі цінностей сталого людського розвитку. Київ : Знання України, 2003. С. 380-382.

11. Олех Л. Г. Цивилизация и революция. Новосибирск : Наука, Сиб. отд-ние, 1989. С. 4.

12. Современная западная социология. Словарь. Москва : Политиздат, 1990. 233 с.

13. Шпенглер О. Закат Европы /Авт. вступ. статьи А.П. Дубнов, авт. комментариев Ю. П. Бубенков и А. П. Дубнов. Новосибирск : ВО «Наука», Сибирская издательская фирма, 1993.592 с.

\section{References}

1. Bekh, V. P. (2015). Phantom of the planetary organism: a look into the future: monograph. V. P. Bekh, I. A. Hrytsiak, O. H. Riabeka. M. P. Drahomanov National Pedagogical University. Kyiv, MP «Lesia». 552.

2. Bek, V. P. (2014). On the threshold of singularity: a planetary community in the vortex of the universe:monograph. V. P. Bekh, Y. V. Bekh. M. P. Drahomanov National Pedagogical University. Kyiv, MP «Lesia». 220.

3. Hrinin, L E., Hrynyn A. L. (2015). The cyber revolution and the sixth technological way. Historical psychology and sociology of history. № 1. 172-197.

4. Erasov, B. S. (1990). Culture, religion and civilization in the East (Essays on general theory). Moscow: Nauka. 87-88.

5. Klimova, G. P. (1997). Education as a phenomenon of civilization / Extended abstract of Doctor's thesis. Kharkov: 60, 415.

6. Korsak, K. (2002). Education and society are guidelines for development. Ridna Shkola, № 5. 7.

7. Martyniuk, S Y. (2002). Genesis of informationalcivilization: monograph - Zaporizhzhia, Prosvita. 192.

8. Marks, K. (1975). To Pavel Vasilyevich Annenkov, December 28. Marks K., Engels F. Essays. 2nd ed. T. 27. Moscow: Publishing House of Political Literature. 402.

9. Marks, K., Engels, F. (1969). Economic manuscripts of 1857-1859. Marks K., Engels F. Essays.-2, Vol. 46, Part 2. Moscow: Publishing House of Political Literature. 222.

10. Ohneviuk, V. (2003). Education in the system of values of sustainable human development. Kyiv: Znannia Ukrainy. 448, 380-382.

11. Olekh, L. H. (1989). Civilization and revolution. Novosibirsk: Nauka, Sib. dep. 4.

12. Modern Western sociology (1990). Dictionary. Moscow: Politizdat. 233.

13. Shpenhler, O. (1993). Zakat Yevropy / Author. introd. article by A.P.Dubnov, ed. comments by Y.P. Bubenkov and A. P. Dubnov. Novosibirsk: VO "Science", Siberian Publishing Company. 592. 
ЗІНКЕВИЧ, В. І. - кандидат сільськогосподарських наук, доцент кафедри менеджменту тапідприємництва, доцент кафедри економіки та менеджменту Дрогобицького державного педагогічного університету імені Івана Франка (Дрогобич, Україна)

E-mail: Zinkevych1971@gmail.com

ORCID iD: https://orcid.org/0000-0003-1004-1685

\title{
АНАЛІЗ ЖИТТЕДІЯЛЬНОСТІ ОСВІТНІХ СИСТЕМ У КОНТЕКСТІ ЦИВІЛІЗАЦІЙНОГО РОЗВИТКУ ПЛАНЕТАРНОГО СВІТУ
}

\begin{abstract}
Анотація
У статті аналізуються залежність явища освіти від типу цивілізації у просторі якої відбувається життєдіяльність світової спільноти в основі якої лежить взаємодія соціальних інститутів ринку, науки і освіти, на поверхню яка «виходить» поділом суспільної праці, що породжує конкретну форму соціальної системи освіти вже у залежності від суспільного поділу праці в конкретних соціально-економічних умовах. Для ефективного відтворення ії структурних і функціональних параметрів пропонується звернутися до парадигми «життєвого циклу освітніх систем у контексті цивілізаційного підходу» на основі використання когнітивного аналізу. Іїі перевага полягає тільки у тому, що даний концепт «схоплює» явище освіти в цілому. Це означає, що явище цивілізаційної освіти вивчається у якості соціального інституту і соціальної системи індустріального суспільства. Для аналізу динаміки зміни знань треба використати дві методологічні умови: застосувати цивілізаційний підхід і парадигму життєвого циклу соціальних систем, оскільки дане явище у просторі і часі має довготривалий вимір; підкреслюється, що знання є базовим і системо утворюючим елементом саморозгортання цивілізації і тому його можна використовувати (за М.Фуко) як методологічний критерій для оцінки якості життєустрою цивілізації; виокремлюється зміст явища освіти на кожному етапі життєдіяльності індустріальної цивілізації: на етапі ії зародження привалювало природниче знання; на етапі зростання - технічне знання, що відповідало суті самої цивілізації; на етапі зрілості - наукове знання перетворилося на ідеологеми соціального розвитку, що привело до появи технократизму і «загнало» планетарну спільноту у глухий кут; на етапі занепаду - технологічне знання призвело до того, що були втрачені орієнтири мейнстриму соціального розвитку і почалась катастрофічна руйнація соціального організму планети, що тягне за собою зміну виду цивілізаційного розвитку; вихід вбачається у підйомі планетарної спільноти у простір інформаційної цивілізації, якому відповідає перехід освіти до оволодіння методологічним знанням.

Ключові слова: освіта, індустріальна цивілізація, соціальний інститут, соціальна система, суспільний поділ праці, життєвий цикл, зародження, становлення, зрілість, занепад.
\end{abstract}

ЗИНКЕВИЧ, В. И. - кандидат сельськохозяйственных наук, доцент кафедры менеджмента и предпринимательства, доцент кафедры экономики и менеджмента Дрогобычского государственного педагогического университета имени Ивана Франко (Дрогобыч, Украина)

E-mail: Zinkevych1971@gmail.com

ORCID iD: https://orcid.org/0000-0003-1004-1685

\section{АНАЛИЗ ЖИЗНЕДЕЯТЕЛЬНОСТИ ОБРАЗОВАТЕЛЬНЫХ СИСТЕМ В КОНТЕКСТЕ ЦИВИЛИЗАЦИОННОГО РАЗВИТИЯ ПЛАНЕТАРНОГО МИРА}

\begin{abstract}
Аннотация
В статье анализируется зависимость явления образования от типа цивилизации в пространстве которой происходит жизнедеятельность мирового сообщества в основе которой лежит взаимодействие социальных институтов рынка, науки и образования, на поверхность которая «выходит» разделением общественного труда, порождает конкретную форму социальной системы образования уже в зависимости от общественного разделения труда в конкретных социально-экономических условиях. Для эффективного воспроизводства ее структурных и функциональных параметров предлагается обратиться к парадигме «жизненного цикла образовательных систем в контексте цивилизационного подхода» на основе использования когнитивного анализа. Ее преимущество заключается только в том, что данный концепт «охватывает» явление образования в целом. Это означает, что явление цивилизационного образования изучается в качестве социального института и социальной системы индустриального общества. Для анализа динамики изменения знаний надо использовать два методологические условия: применить цивилизационный подход и парадигму жизненного цикла социальных систем, поскольку данное явление в пространстве и времени имеет длительное измерение; подчеркивается, что знание является базовым и системо образующим элементом саморазвертывания цивилизации и поэтому его можно использовать (по М. Фуко) как методологический критерий для оценки качества жизнеустройства цивилизации; выделяется содержание явления
\end{abstract}

(C) Zinkevych, Vasyl, 2021 
образования на каждом этапе жизнедеятельности индустриальной цивилизации: на этапе ее зарождения доминировало естественное знание; на этапе роста - техническое знание, что соответствовало сути самой цивилизации; на этапе зрелости - научное знание превратилось в идеологемы социального развития, что привело к появлению технократизма и «загнало» планетарное сообщество в тупик; на этапе упадка - технологическое знание привело к тому, что были потеряны ориентиры мейнстрима социального развития и началось катастрофическое разрушение социального организма планеты, что влечет за собой изменение вида цивилизационного развития; выход видится в подъеме планетарного сообщества в пространство информационной цивилизации, которому соответствует переход образования к овладению методологическим знанием.

Ключевые слова: образование, индустриальная цивилизация, социальный институт, социальная система, общественное разделение труда, жизненный цикл, зарождение, становление, зрелость, упадок.

(C) The Author(s) 2021

This is an open access article under the Creative Commons CC BY license
Received date 07.03.2021

Accepted date 17.03.2021

Published date 21.03.2021

How to cite: Zinkevych, Vasyl. Life activity analysis of educational systems in the context of civilizational development of the planetary world. Humanities studies : Collection of Scientific Papers. Zaporizhzhia: Zaporizhzhia National University, 2021.7 (84), P. 15-21.

doi: https://doi.org/10.26661/hst-2020-7-84-02 